\title{
NEW FORMS OF URBAN GOUERNANGE: BUSINESS IMPROVEMENT DISTRICTS AND THE CHALLENGES OF THEIR INTRODUGTION IN SPAIN
}

\section{NUEVAS FORMAS DE GOBERNANZA URBANA: LOS BUSINESS IMPROVEMENT DISTRICTS Y LOS DESAFÍOS DE SU INTRODUCEIÓN EN ESPAÑA}

\section{HELENA VILLAREJO GALENDE}

Senior Lecturer of Administrative Law (Profesora Titular de Derecho Administrativo) Facultad de Ciencias Económicas. Universidad de Valladolid.

Avenida Valle Esgueva, 6. 47011 Valladolid (Spain)

E-mail: helenav@eco.uva.es

\section{MARÍA LUISA ESTEVE PARDO}

Senior Lecturer of Tax Law

(Profesora Titular de Derecho Financiero y Tributario) Facultad de Derecho. Universitat de Girona Calle de la Universitat, 12. 17003 Girona (Spain).

E-mail: luisa.esteve@udg.edu

\section{KEY WORDS}

Business Improvement Districts, downtown redevelopment, public-private partnerships, urban governance, urban regeneration, town center management

\section{PALABRAS CLAVES}

Business Improvement Districts, desarrollo urbano, colaboración public.privada, gobernanza urbana, regeneración urbana, gestión de centros urbanos 


\section{Abstract}

Within the context of the decentralisation and privatisation processes facing local governments, Business Improvement Districts (BIDs) can be considered as a paradigm of the evolution of urban policies in recent years. BIDs are organizations of a private nature or are public-private partnerships with local authorities, created when a majority of the business owners or business premises owners in a delimited area agree, by means of a ballot process, to manage the zone to offer more supplementary services funded by a mandatory charge with the aim of boosting the economy and regenerating the area. Since their appearance in Canada over four decades ago, this new form of public-private partnership in the local government sphere has spread to different cities in other countries, most notably to the USA, the UK and Germany.

BIDs have proved to be a creative and very efficient mechanism of urban governance, capable of satisfactorily combining the public and private interests at play. Establishing a $B I D$ is a democratic process that guarantees the involvement of all the stakeholders. The key to their effectiveness is that they have a source of sustained funding, sufficient to allow them to improve the provision of urban services. Introducing the BID model in Spain could serve not only to boost urban commercial areas, but also other environments where there is economic activity, such as industrial parks and tourist destinations.

The aim of this communication is to analyse comparative experiences in the BID model and to examine, from a legal point of view, which measures and legal reforms would be required to transfer this public-private partnership formula to the Spanish legal system. 


\section{Resumen}

Los Business Improvement Districts pueden ser contemplados como un paradigma de la evolución de la política urbana en los últimos años, en el contexto más amplio de los procesos de descentralización y privatización que afrontan los gobiernos locales. Se trata de organizaciones de carácter privado, o consorciado con las autoridades locales, creadas cuando la mayoría de empresarios o propietarios de locales de negocios de un área delimitada acuerdan, mediante un proceso de votación, gestionar, gracias al pago de contribuciones de carácter obligatorio, una mayor oferta de servicios adicionales dirigidos a la promoción económica y regeneración del área. Desde que nacieran en Canadá, hace más de cuatro décadas, esta nueva forma de colaboración público-privada en el ámbito del gobierno local se ha expandido por todo el mundo, desarrollándose especialmente en Estados Unidos, Reino Unido o Alemania.

Los BID han demostrado ser un mecanismo creativo y muy eficaz de gobernanza urbana, capaz de articular satisfactoriamente los intereses públicos y privados en juego. Su característico proceso democrático de constitución garantiza la implicación de los sujetos afectados. Al tiempo, la clave de la efectividad de los BID es que disponen de una fuente de financiación suficiente y sostenida en el tiempo, que les permite mejorar la prestación de servicios urbanos. La introducción del modelo BID en España podría servir para dinamizar los centros comerciales urbanos y otros entornos donde haya actividad económica, como los polígonos industriales o los destinos turísticos.

Esta comunicación tiene como principal objetivo analizar las experiencias comparadas del modelo BID y examinar, desde un punto de vista jurídico, qué medidas y reformas legislativas serían necesarias para trasladar apropiadamente este modelo de gobernanza urbana al ordenamiento jurídico español, así como la problemática que las acompaña. 


\section{Objectives}

The purpose of this communication is to analyse comparative experiences in the BID model and to examine, from a legal point of view, which measures and legal reforms would be required to transfer this public-private partnership formula to the Spanish legal system.

\section{Methodology}

To accomplish these objectives, we rely on a multi-method qualitative and quantitative research design, collecting data from a range of primary and secondary sources. Primary data collection involved the execution of semi-structured personal interviews with BID managers, stakeholders and government officials in several cities. Secondary sources included BID enabling legislation, public hearing transcripts, scholarly papers, newspaper articles, conference proceedings, trade magazines, BID web sites and newsletters.

Through the review of primary and secondary sources we have analysed the BID experiences in Canada, USA, United Kingdom and Germany in order to establish the main characteristics of the international BID model. Once a comparative analysis of the BID model have been done, using the same methodological approach, the main issues of the urban economy in Spanish cities and the way the BID model can face them have been identified, in order to design the main features of a Spanish BID from a legal point of view.

"Nothing in this world is more simple and more cheap than making cities that provide better for people"

JAN GEHL, 2013

\section{New forms of urban governance in XXI century cities: Business Improvement Districts as a paradigm of creativity and innovation in public administration}

A 'silent revolution' has been taking place in public administration in recent years (Salamon, 2002), which has brought about a fundamental change in the decision-making process: the public sector has begun to embrace initiatives and proposals from the private and third sectors and to include these agents as managers and financers of public policies (Morçól et al., 2008). The result has been the blurring of the division between states and markets and an unprecedented level of innovation in the design of new policy tools.

Urban regeneration is one of the areas where new forms of public management are considered. Despite continuing to be large projects driven and funded by the public sector, initiatives at a local level are increasingly emerging from the private sector. This change poses a huge challenge from the point of view of local governance as it requires tight collaboration between public and private agents, which demands 
clearly defined and designated powers and responsibilities (Villarejo, 2014). A new model of governance that incorporates these challenges is therefore needed (Morçöl \& Wolf, 2010). A new form of public-private collaboration within the sphere of local government has been proliferating in North American cities for over four decades, from where it has spread to many other countries. They are the Business Improvement Districts (BIDs), public-private partnerships where the majority of business or property owners decide to make mandatory payments with the aim of maintaining, developing and promoting their business district. BIDs exemplify publicprivate collaboration within the framework of urban regeneration with their interesting combination of business initiative and public funding (Houstoun, 1997). From both a theoretic and a practical point of view, BIDs have acquired enormous importance due to their singular form of organisation, their increasing numbers and their geographic spread, as well as the administrative and economic power they wield.

BIDs can be seen as a paradigm of how urban policies have evolved in recent years, exemplifying the tendency towards decentralisation and privatisation that is challenging local governments in the context of the economic globalization. On the one hand, federal, central and regional governments have transferred many tasks to local government, while they, on the other hand, are handing many functions over to the private sector in line with the other levels of government (Borja y Castells, 1996; Davies, 1997: 187; Lloyd et al, 2003:296).

Local authorities have long been a source of creativity. This spirit of innovation has brought about a fundamental rethinking of municipal government: the government must be much less involved in the direct provision of services and more involved in ensuring that these services are provided. As Mitchell (1999: 9) has pointed out, BIDs are thus 'a conspicuous illustration of creative thinking at the local level.'

Authors like Briffault (2010) affirm that the growth in the number of BIDs over the last few decades suggests that there is 'great value' in an institutional model that allows additional income to be obtained from business or property owners in a particular district, which is then assigned to funding programmes and activities within that geographical area, rather than the local authority being solely relied on to provide public services. BIDs allow communities to assess their particular needs and to provide additional services. Furthermore, they ensure that it is the local members of the community themselves who decide what their priorities and preferences are and exactly what services they will supplement and what activities they will develop (Briffault, 2010: 22).

\section{General perspective of the BID model}

\subsection{Definition, origin and international expansion}

BIDs can be defined as 'self-assessment districts that are usually initiated and governed by property or business owners, enabled by state laws, and authorised by local governments to provide public services in designated urban and suburban areas' (Morçöl y Wolf, 2010: 906). To understand this model, it is essential to bear in mind that it is the property owners (or businesses) in a delimited geographical area themselves 
who agree by a majority vote to provide additional public services through charging a levy or compulsory assessment on all the property and business owners located in the area (Mitchell, 1999: 6). Examples of services that can be provided include additional cleaning, supplemental security, making capital improvements or consumer marketing and branding of the district. Emphasis must be placed on the revitalizing aim of the model, given that the BIDs are created to offer supplementary services to regenerate and boost the area economically (Villarejo, 2014: 235).

The model emerged as a private sector initiative to regenerate urban centres and to combat decentralisation (Hoyt, 2007: 947). In the mid-1970s, a small group of business owners in Toronto came up with a way of solving the problem of 'free-riders' who did not cooperate economically but did benefit from the initiatives and improvements carried out and funded by the members of the voluntary business association. They explored the possibility of creating a privately managed autonomous entity with the power to impose a charge on all the business owners in the district to fund local revitalization initiatives (Houstoun, 1997; Holter, 2002). To do this, a specific enabling legislation had to be passed, which the province of Ontario did in 1969. Six months later, the City of Toronto passed bylaw No. 170-70 and the world's first BID, Bloor West Village, became a legal reality (Hoyt, 2006: 229). Given the initial success of the model and the advantages it brought, BIDs quickly spread first throughout the rest of Canada (Hernandez y Jones, 2006: 795) and later to the USA. According to an International Downtown Association survey, there are currently more than 1000 BIDs in the USA, 74 of which are in the city of New York alone. BIDs have since appeared all over the world, from Australia to Japan and throughout Europe, including Germany, the Netherlands, Ireland, Sweden and the UK (Ward \& Cook, 2017), as an example of the global phenomenon of the mobility of urban policies (Ward, 2006; Cook, 2008; Peck y Theodore, 2010; Peyroux et al. 2012).

In Europe, BIDs were first imported into the UK with the passing of the Local Government Act in 2003 and its legislative development in 2004 (England) and 2005 (Wales). In Scotland, the Planning Act was passed in 2006 and in Northern Ireland the Business Improvement Districts Act came into force in 2013. Currently, there are about 300 BIDs operating across the UK (BritishBIDs, 2016), not only in large cities (more than 50 in London), but also in towns and rural areas. It was the city-state of Hamburg that pioneered BIDs in Germany by passing specific legislation in December 2004, shortly after which the city's first two BIDs (BID Sachsentor and BID Neuer Wall) were created. In January 2007, a new paragraph was added to the Federal Code of Urban Planning (Baugesetzbuch-§171f BauGB), under the heading 'private initiatives in urban development' (Private Initiativen zur Stadtentwicklung). Based on this precept, the Länder can now pass specific laws to promote private initiatives aimed at developing and regenerating specific urban areas (Friesecke, 2006; Kreutz, 2009; Brenner, 2010; Eick, 2012). To date, ten Länder have now done so (DIHK, 2017) and there are currently 30 BIDs functioning in Germany and almost 100 in the process of being set up (Costela, 2017), which has led some commentators to claim about the "BIDization" of German cities (Eick, 2012, 2014).

The rapid growth in the number of BIDs is the response to various socioeconomic and political factors; the decline of cities centres, together with urban sprawl caused by the development of an extensive network of 
motorways; the proliferation of new commercial formats; the problems of organizing and financing municipalities; and the tendency to turn to public-private companies and partnerships to promote urban regeneration.

\subsection{Formation, finances and functions}

Despite the model varying from country to country, and even from one state to another in the case of federal states, BIDs are usually created by municipal decision and authorised by state law. In the USA, their formation is usually driven by a significant part of the business and property owners in the area, who also propose the boundaries of the district and develop its funding and business plan (Briffault, 1999: 368-369). Most state laws establish a two-stage procedure to set up a BID. First, the interested parties (property owners, shopkeepers and business owners) must vote in a ballot to authorise the creation of a BID in the area and then the local authority must pass an ordinance (a city government statute) by which the BID is formally established and its boundaries, functions, budget and way of funding addressed.

The process to set up a BID is democratic and usually requires that a ballot process take place to demonstrate that there is a majority in favour. In the USA, state legislation often contemplates relatively high approval rates and weighted voting systems that combine criteria of the number of property owners and the property value they represent.

In the UK, BIDs must pass a 'double test' in a ballot process where each business owner ('non domestic ratepayers') who must pay the levy in the designated area has the right to vote. The BID proposal or Business Plan must receive the majority affirmative vote of numbers of voters and also, the rateable value (the open market rental value, based on an estimate by the Valuation Office Agency) of the properties of the business owners who voted in favour must be higher than the rateable value of the properties of those who voted against (Cook, 2009).

In Germany, it is the property owners who decide: they pay and they vote. Pursuant to Hamburg legislation (GSED), the initial BID proposal must be backed by just $15 \%$ of the property owners in the proposed area, who must represent at least $15 \%$ of the total surface area in question. Once the business plan of the future BID is accepted by the local authority, the application is made public for one month. If the affected property owners who explicitly reject the proposal represent more than a third of the total (again in both quantitative and qualitative terms), the BID will be approved by the City Council and all the property owners within the boundaries of the BID will be charged an additional tax based on the value of their properties (Kreutz, 2009: 308; Brenner, 2010: 222).

Regarding the system of funding, all countries that have regulated BIDs establish the obligation to pay a charge to fund them. In the US, the formula they use is called 'assessment' or 'BID fee' and is legally configured as a tax that the property owners must pay specifically to fund the actions the BID develops (Briffault, 1999: $370)$. As a general rule, this tax is between 8 and $10 \%$ of the property tax charge. This is the main source 
of BID funding and can be as much as hundreds of millions of dollars a year depending on the value of the business premises, the size of the business district and the tax revenue formula employed (Mitchell, 1999: 17).

The biggest difference between the English and Welsh models and the US model is that in England and Wales instead of property owners it is the business owners (those who rent the business premises) who must pay the BID 'levy', which is collected by the local tax authority in addition to their non-domestic business rates bill (Cook, 2008). The additional BID levy is determined by each BID and does not usually exceed $1 \%$ of the rateable value of each business. The amount collected through the BID levy ranges from 22,400 pounds sterling in London New Addington to 2,814,000 pounds sterling in London New West End Company (BritishBIDs, 2016).

In Germany, the property owners in the district must pay a 'special tax' (Sonderabgabe), which is basically calculated from two parameters; the budget of the BID and the equivalent of the rateable value of the properties encumbered. After deducting administrative costs, the City Council hands the remaining amount over to the BID management. The amount collected varies enormously from one BID to another. For example, the Neuer Wall BID in Hamburg invested almost six million euros in the area by 2010 and approved an additional 2.3 million euros for the period 2011-2016.

In all the models compared, the levies paid by the members of the BID are generally collected together with the municipal authority local taxes and are later transferred to the BIDs management entity or body (normally, they are not-for-profit companies) to be spent on the actions and services it provides.

Even though the actions developed by the BIDs vary significantly from one to the other and even within the same locality, they generally focus on (Hochleutner, 2003: 380; Ward, 2007; Mitchell, 2008):

a. Cleaning and maintaining the public space, improving the appearance of the urban landscape (cleaning and maintaining the streets, removing graffiti, collecting litter, paving walkways, signposting and lighting, installing benches and rubbish bins, planting trees and flowers etc.)

b. Security of the public spaces and the businesses (through employing private security staff and installing security cameras to prevent crime and to make the business owners, staff and consumers feel safer.)

c. Marketing and the economic promotion of the area of the BID and organising events to compete with other areas inside and outside the city.

Some of the most ambitious BIDs have dealt with the problems of parking and traffic and others have tackled urban uses, transport and social services for the homeless (Briffault, 1999: 401-404).

However, BIDs neither seek to replace the local authority in providing services (Briffault, 1999: 400) and nor can they be used to justify the local government withdrawing and causing the public spaces to be privatised. Some studies on this particular point (Meltzer, 2010) have analysed whether there are any 
significant differences in the provision of public services in the city of New York between areas with BIDs and areas where there are none. The conclusion is that the local authority does not relinquish functions once the BID is established in the area.

In most countries, the lifespan of a BID is limited to just a few years (usually five), but what is certain is that they are rarely dissolved. On the contrary, BIDs are periodically renewed through new authorization procedures, which are contemplated by the legislation of each state and are usually the same as the ballot processes established for the initial setup (Houstoun, 2003: 33; Kreutz, 2009: 308; Ward y Cook, 2014). The renewal rate of BIDs is very high and in the second and successive renewals both the approval percentages and participation in the ballot process increase (Costela, 2016: 10).

\section{Proposal for adapting the BID model in Spain}

\subsection{General characteristics}

In brief, our proposal is that the Spanish BIDs have the following characteristics:

1st. The initiative to establish a BID must always come from a significant group of economic operators located in a specific area of a municipality. Even though this type of joint action has to date been developed mainly by retailer's associations, we propose that any group of economic agents with heterogenous business activities united by a common interest to promote competitivity and improve the attractiveness of their area of the city can establish a BID.

2nd. This steering group will be responsible for proposing the idea to establish the BID to the other economic operators in the area, for determining the BID area boundary and for producing a business plan (which must include details of the BID charge of each operator). The steering group has to gather the support needed to go ahead with the proposal falls, of course, to the. Once a significant proportion of the economic operators in the area support the initiative, the steering group will ask the City Council for approval. The BID Proposal documents must include a business plan, including the revenue and expenditure budget. The City Council will examine the BID Proposal and decide if the business plan is compatible with the general interests and town planning of the municipality and to ensure that the future actions of the proposed BID neither encroach on public competencies nor substitute the public sector or privatization in any way in their task of managing the public spaces. The City Council will then submit the application to public scrutiny, stating clearly that the BID proposal must be supported by the affected economic operators. If the proposal has enough support, the City Council will approve the BID.

There are different ways to measure this support: by means of an open ballot among all the affected parties or by other means that provide indisputable, documented proof of the acceptance or rejection 
of the proposal. The support for the City Council to approve the BID application can be required either positively or negatively. In other words, the Council can require that a certain percentage of those affected manifest their support for the proposal or that a significant minority manifest that they do not support the proposal. As mentioned previously, our knowledge of comparative law shows that there are a wide range of alternatives in this sense. The possibility of introducing weighted voting systems should also be considered.

3rd. Once the BID is approved by the City Council, their collaboration with the BID is formalized by signing an agreement or public contract whereby the BID commits to carrying out the proposed business plan and to applying the funds correctly. The agreement or contract can be terminated if breached.

4th. BIDs are managed by private non-profit bodies or public-private partnerships. Membership to the BID is voluntary and any of the economic operators obliged to pay the BID charge can become members. While membership is not mandatory, payment of the BID charge is.

The City Council will be represented in the organs of government of the entity as non-voting members to ensure that the BID activity is in line with public interests.

The organs of government of the entity that manages the BID can include: a General Assembly the supreme organ of the entity, made up of all the members; a Board of Directors - elected by the General Assembly and must include two City Council representatives as non-voting members; a Chairman - holder of the legal representation of the entity; and the Management - executive organ of the agreements of the General Assembly and the Board of Director. The business plan and the budget of the BID must be approved by a majority of the voting members of the BID at the General Assembly.

5th. The actions and services of the BIDs focus on aspects like image campaigns, event organisation and other services to promote, regenerate and raise the attractiveness of the area: to remove graffiti, manage the occupation of empty premises, improve the business mix, provide a consultancy service for members (the presence of social networking sites, quality indicators, e-commerce, etc.), provide common services, create networks to improve security for the premises, etc. (Costela, 2016: 12-13). BIDs' services are provided in addition to those offered by local governments and must, therefore, run concurrently with them and in no way substitute them. Two dangers are thereby avoided: that the BID does not replace the public sector in their tasks and powers and that the local authority does not reduce or withdraw the services they provide in the area using the argument that the BID is now responsible for them.

6th. The budget of the BID is mainly covered by the BID charge, the basic characteristics of which are:

- The charge for each new BID will be established and imposed by municipal ordinance, 
pursuant to state legislation

- $\quad$ Taxpayers are those who carry out an economic activity in the area

- The amount of the BID charge is to be calculated on these elements: the budget of the BID and the rateable value of the business premises. Other elements can be considered, such as where exactly in the BID the premises is located (if it is on a main thoroughfare or in a less frequented spot) and accessibility from the public highway, etc.

- Relief and extensions can be established depending on criteria such as the type of activity developed (charity, cultural, general interest, etc.), economic capacity and so on (Costela, 2016: 10-11).

- The City Council is responsible for collecting the charge and we propose that it is collected together with the Property Tax (Impuesto sobre Bienes Inmuebles - IBI), but itemised separately on the bill.

- The City Council will hand over the amount collected in BID charges to the BIDs governing body.

This mandatory charge is not the BID's only source of income. Other possible sources are: voluntary contributions made by specific taxpayers or companies, public aid, payment for its services, external investors, etc.

In the UK, one of the biggest advantages of BIDs has been shown to be the dynamics they generate, attracting new resources and investments (Costela, 2016: 10-11). According to data from the organisation British BIDs (Nationwide Survey, 2015:10), the BID levy collected by all the BIDs established in the UK in 2015 totalled 80,125,000 pounds sterling and additional income stood at $62,967,310$ pounds sterling. A total of $143,092,297$ pounds sterling has been invested this year in areas where there are BIDs.

7th. BIDs have a limited lifespan: they are approved to operate for four or five years. The usual effective term in comparative law is five years, after which the BID can be renewed if the same requisites as for the initial setup are complied with. Limitations like this on the effective term for BIDs maximises accountability and taxpayers' assessments of how the income from the levy has been managed.

8th. The City Council is responsible for monitoring and supervising the BID to ensure that the business plan is being effectively implemented and that the BID charges are being used correctly, in accordance with the budget. The powers assigned to the local authority should be strictly limited to monitoring and supervising the BID, as comparative experience has shown that greater local government intervention leads to the BID becoming simply a local authority instrument with no capacity of initiative. 


\subsection{Necessary legislative reform}

This proposal means that various laws need to be modified or specific legislation has to be passed.

Specific matters require the intervention of the state legislator.

Regulation of the BID charge, in that it must be paid by all the economic operators within the BID, undoubtedly constitutes a public charge which, in accordance with Article 31.3 of the Spanish Constitution, can only be established by law. Beyond the fact that the BID charge is a public charge, it legal nature is unclear. Despite the levy being assigned to funding expenses of a private nature - given that the BIDs are private entities - some features of it approximate it to a tax. In fact, in all the foreign legislation analysed here - that of the USA, the UK and Germany - the charge is, in fact, a tax, even though its specific typology is different in each case and in the US it is called an assessment or fee and in the UK it is classed as a levy, categories which are unknown in our tax system. In Germany, the tax used is the Sonderabgabe, a specific type of tax that is different from the three tax categories in both the German and Spanish systems - taxes, rates and contributory taxes - and has been recognised and accepted in German case law and legal doctrine and has a clearly defined profile. The Sonderabgaben was established with the aim of covering certain expenses not with general taxes but with charges that only the group that are verified to benefit most from a particular action must pay (Esteve, 2015: 34-44).

In any case, given the similarities between the BID charge and a tax, introducing the BID charge in Spain will mean modifying the Local Government Finance Act, which is a state law.

The simplest option would be to add a new section to Article 72 of the Local Government Finance Act, which would regulate the BID charge depending on the rateable value of the business premises and establish that it be collected with the municipal Property Tax (IBI). Thus, even though the BID charge would operate as if it were a surcharge on this tax, it could not be legally categorized itself as a tax, but as a public charge.

Once the BID charge is regulated by a state law, BIDs could be establish in Spain. BID proposals could be submitted to the City Councils and their formation approved by Ordinance, which would also impose the BID charge and define other specific elements.

The power to regulate BIDs, their existence, their specific characteristics, their proposal approval process, their organisation and operation, etc., falls to the Autonomous Communities pursuant to the powers they have, and especially to the powers they have in matters of economic development.

The laws of each Autonomous Community will probably be different, as their economic backgrounds, their needs, the typology of their municipalities and their economic activity vary. This happens, for example, in Germany, where some aspects of the legislation in the different Länder vary. In fact, the proposal we are making here is not completely closed and different options are offered. Even though the models of comparative law certainly have common elements, they also have numerous differences, which clearly illustrates our point: 
the BID model must adapt to the specific situation and requirements of each place.

This is one of the major strengths of BIDs: their flexibility and adaptability. And this must be facilitated by a legal framework that leaves enough room for each BID to be able to adapt to the characteristics, priorities and needs of their members and the cities where they are located.

For this reason, and out of basic respect for local autonomy, it is essential that regional legislation leaves a wide room for decision-making so that local authorities can make their own decisions about BIDs and approve their own Ordinances.

It must not be forgotten that the final decision about whether or not to approve the establishment of a BID rests with the City Councils and economic and social urban development are local policies.

\section{Conclusions}

\section{First}

BIDs are a worldwide success as a new model of municipal governance. Its rapid expansion across the different continents and the high number of BIDs operating in the different cities all over the world are a good indicator that they are a good tool for urban centers management and shows the satisfaction of the stakeholders.

\section{Second}

Despite some criticisms, BIDs are effective because they provide sustainable funding for an agreed period of time, allowing the private sector to work with the local authorities to deliver a variety of projects aimed at improving their business environment. In general, they are considered a good instrument in the hands of local governments to prevent urban degeneration and to stimulate economic development (Reynolds, 2015).

The benefits of BIDs are clear in two areas:

1. reductions in crime

2. positive impact on the value of commercial property (Hoyt, 2005).

It has also been noted that they participate actively and positively in urban governance (Morçöl et al., 2014), so that it can be said that they are 'net contributors to public life' (Briffault, 1999: 477).

\section{Third}

BIDs are the best response to the problems currently facing the urban economy in Spain and a good way to solve the pressing financing needs arising from the crisis. As a matter of fact, many public administrations, 
private organizations and political parties have expressed their interest in the potential development of this model. Considering its long history and proven success, we believe that the time has come to introduce the BID model in Spain.

\section{Fourth}

In our opinion, the main features of a Spanish BID should be:

- The initiative to establish a BID must always come from the private sector, from economic operators

- If the proposal has enough support, the City Council will approve the BID

- The collaboration between the BID and the City Council is formalized by signing an agreement or public contract

- BIDs are managed by private non-profit bodies or public-private partnerships

- BIDs' services are provided in addition to those offered by local governments and must, therefore, run concurrently with them and in no way substitute them

- The budget of the BID is mainly covered by the BID charge, a compulsory charge levied by the City Council

- BIDs have a limited lifespan: they are approved to operate for four or five years

- The City Council is responsible for monitoring and supervising the BID

\section{Fifth}

In regional and local levels of government flexible solutions should be developed to help Spanish BIDs to maximize their creative potential to improve business and neighborhood quality and meet the needs of the public and private interests at play.

\section{Note}

* This communication is part of the Project "Public-private partnership and fiscal consolidation: BID and ECAs" (DER2015-65148-C2-1-P) financed by the Spanish Ministry of Economy and Competitiveness (State Program for the promotion of scientific and technical excellence research - 2015 call). 


\section{References}

- Borja, J. \& Castells, M. (1996). Local and Global: Management of Cities in the Information Age. London: Earthscan.

- $\quad$ Brenner, J. (2010). "Private initiatives in German urban development policy", Urban Research \& Practice, Vol. 3, No. 2: $219-228$.

- Briffault, R. (1999). "A Government for Our Time? Business Improvement Districts and Urban Governance", Columbia Law Review, 99 (2): 365-477.

- $\quad$ Briffault, R. (2010). "The Business Improvement District comes of age”, Drexel Law Review, Vol. 3: 19-33.

- $\quad$ BritishBIDs (2016). Nationwide BID survey 2016. Ipswich: BritishBIDs.

- $\quad$ Cook, I. R. (2008). "Mobilising urban policies: the policy transfer of US Business Improvement Districts to England and Wales", Urban Studies 45 (4): 773-795.

- $\quad$ Cook, I.R. (2009). "Private sector involvement in urban governance: The case of Business Improvement Districts and Town Centre Management partnerships in England", Geoforum, 40: 930-940.

- $\quad$ Costela Sánchez, A. (2016). "Los Business Improvement Districts (BIDs): implantación en Europa, experiencia en el Reino Unido, y futuro", Comunicación presentada en el VII Congreso Internacional en Gobierno, Administración y Políticas Públicas (GIGAPP) celebrado en Madrid en octubre de 2016, http://www.gigapp.org/administrator/components/ com_jresearch/files/publications/2016-234.pdf

- Costela Sánchez, A. (2017). «Los Business Improvement Districts (BIDs) alemanes como modelo para España», Comunicación presentada al VIII Congreso Internacional en Gobierno, Administración y Políticas Públicas (GIGAPP) celebrado en Madrid en septiembre de 2017, https://congreso.dryfta.com/components/com_dryfta/assets/congreso/ abstractfiles/abs_343_1504560528AlvaroCostelaPonenciaGIGAPP2017.pdf

- $\quad$ Davies, M. S. (1997). "Business Improvement Districts”, Journal of Law and Contemporary Law, Vol. 52: 187-223.

- $\quad$ DIHK (2017). Deutscher Industrie- und Handelskammertag - BID News 30/2017. [online]. Available at: https://www. dihk.de/themenfelder/wirtschaftspolitik/info/bidnews/aktuell/bidnews-30-17-engl/at_download/file?mdate=149969234088

- $\quad$ Eick, V. (2012). "The co-production of purified space: hybrid policing in German Business Improvement Districts", European Urban and Regional Studies, 19(2): 121-136.

- $\quad$ Eick, V. (2014). "Emerging semi-states: The BIDisation of German Cities". Integrating interests: future-proofing city centre retail economies? University of Sheffield, School of Law. 31 March 2014. Available at: http://www.sheffield.ac.uk/ polopoly_fs/1.366953!/file/VolkerEick_EmergingSemi-States.pdf

- $\quad$ Esteve Pardo, M.L. (2015). "Un recargo sobre el IBI como posible fórmula para financiar los planes públicoprivados de dinamización comercial”, en Marta Villar Ezcura, coord., Estudios sobre el sistema tributario actual y la situación financiera del sector público. Homenaje al Profesor Dr. D. Javier Lasarte Álvarez. Instituto de Estudios Fiscales (IEF): Madrid.

- $\quad$ Esteve Pardo, M.L. (2015). "Financiación de actuaciones público-privadas de promoción del comercio urbano mediante tributos: la experiencia alemana", Quincena Fiscal, $n^{\circ} 22:$ 21-47.

- $\quad$ Friesecke, F. (2006). "Revitalization of Urban Areas through Business Improvement Districts (BID)-Trends and Expectations for Shrinking Cities", Promoting Land Administration and Good Governance. 5th FIG Regional Conference. Accra, Ghana, March 8-11.

- Hernandez, T. \& Jones, K. (2005). «Downtowns in transition. Emerging business improvement area strategies», International Journal of Retail \& Distribution Management, Vol. 33, No. 11: 789-805.

- Hochleutner, B.R. (2003). «BID fare well: The democratic accountability of Business Improvement Districts», New York University Law Review, vol. 78: 374-404. 
- Holter, D. (2002). BID: A Quiet Revolution in Urban Management. California Policy Options, 47-52.

- $\quad$ Houstoun, L.O. (1997). BID: Business Improvement Districts, Washington, D.C.: Urban Land Institute.

- Hoyt, L.M. y Gopal-Agge, D. (2007). «The Business Improvement District Model: A Balanced Review of Contemporary Debates», Geography Compass, 1 (4): 946-958.

- Hoyt, L.M. (2006). «Importing ideas: The transnational transfer of urban revitalization policy», International Journal of Public Administration, vol. 29: 221-243.

- $\quad$ Hoyt, L. M. (2005), “Do Business Improvement District Organizations Make A Difference? Crime In and Around Commercial Areas in Philadelphia”, Journal of Planning Education and Research, 25: 185-199.

- $\quad$ Kreutz, S. (2009). "Urban Improvement Districts in Germany: New legal instruments for joint proprietor activities in area development", Journal of Urban Regeneration and Renewal, Vol. 2, 4: 304-317.

- Lloyd, G., McCarthy, J., McGreal, S. y Berry, J. (2003). «Business Improvement Districts, planning and urban regeneration», International Planning Studies, vol. 8, issue 4: 295-321.

- $\quad$ Meltzer, R. (2010). "Clean and Safe" for All? The Interaction Between Business Improvement Districts and Local Government in the Provision of Public Goods. National tax journal, 64(3).

- $\quad$ Mitchell, J. (1999). Business improvement districts and innovative service delivery, The PricewaterhouseCoopers Endowment for the Business of Government, New York.

- $\quad$ Mitchell, J. (2008). Business Improvement Districts and the Shape of the City. Albany, NY: State University of New York Press.

- Morçöl, G., Hoyt, L., Meek, J. W., \& Zimmermann, U. (2008). Business Improvement Districts. Research, Theories and Controversies. Nueva York: CRC Press.

- $\quad$ Morçöl, G., \& Wolf, J. (2010). Understanding Business Improvement Districts: A New Governance Framework. Public Administration Review, 70(6), 906-913.

- $\quad$ Morçöl, G.; Vasavada, T.; Kim, S. (2014). "Business Improvement Districts in Urban Governance: A Longitudinal Case Study", Administration \& Society, Vol. 46 (7): 796-824.

- $\quad$ Peck, J. \& Theodore, N. (2010). "Mobilizing policy: Models, methods, and mutations". Geoforum, 41 (2), $169-174$.

- $\quad$ Peyroux, E., Pütz, R. \& Glasze, G. (2012). "Business Improvement Districts (BID): The internationalization and contextualization of a travelling concept", European Urban and Regional Studies, 19 (2): 111-120.

- $\quad$ Reynolds, L. (2015), "BIDs in the U.S.: Policy Perspectives After the First 25 Years". Document presented in the International Seminar "De los Business Improvement Districts a las Áreas Comerciales Urbanas", Madrid, March.

- $\quad$ Salamon. L. M. (2002). The Tools of Government: A Guide to the New Governance. Nueva York: Oxford University Press.

- Villarejo Galende, H. (2014). „Colaboración público-privada para la revitalización de espacios urbanos: la introducción de los Business Improvement Districts en el ordenamiento jurídico español". Revista de Gestión Pública, III (2), 235-277.

- Villarejo Galende, H. y Esteve Pardo, M.L. (2017). Propuesta normativa para la implantación de los BID en España. AGECU, Valencia.

- Ward, K. \& Cook, I.R. (2014). "Business Improvement Districts in the UK: Territorialising a 'global' model?", Imagining Urban Futures Working Paper 13. Available at: http://research.northumbria.ac.uk/urbanfutures/wp-content/ uploads/2012/03/Ward-and-Cook-2014-BID-in-the-UK.pdf

- Ward, K. (2006). "'Policies in motion', urban management and state restructuring: The trans-local expansion of Business Improvement Districts», International Journal of Urban and Regional Research, 30 (1): 54-75. 